\title{
Solution-sol-gel processing of superconductors
}

\author{
S KOMARNENI, P RAVINDRANATHAN, A S BHALLA and \\ R ROY \\ Materials Research Laboratory, The Pennsylvania State University, University Park, PA \\ 16802, USA
}

\begin{abstract}
Bulk materials and thin films of pure and homogeneous $\mathrm{YBa}_{2} \mathrm{Cu}_{3} \mathrm{O}_{7-x}$ and $\mathrm{Bi}_{2} \mathrm{Sr}_{2} \mathrm{CaCu}_{2} \mathrm{O}_{8+x}$ compounds were prepared by a nanocomposite solution-sol-gel (SSG) method. The superconducting oxides of $\mathrm{YBa}_{2} \mathrm{Cu}_{3} \mathrm{O}_{7-x}$ and $\mathrm{Bi}_{2} \mathrm{Sr}_{2} \mathrm{CaCu}_{2} \mathrm{O}_{8+x}$ were prepared at very low temperatures i.e. $750^{\circ} \mathrm{C}$ and $850^{\circ} \mathrm{C}$, respectively by SSG method. Pellets sintered from these nanophasic sol powders showed sharp resistivity drops at $T_{\mathrm{c}} \sim 90^{\circ} \mathrm{K}$ for $\mathrm{YBa}_{2} \mathrm{Cu}_{3} \mathrm{O}_{7-x}$ and $T_{\mathrm{c}} \sim 67^{\circ} \mathrm{K}$ for $\mathrm{Bi}_{2} \mathrm{Sr}_{2} \mathrm{CaCu}_{2} \mathrm{O}_{8+x}$. Thin films were prepared using triphasic sol of $\mathrm{Y}, \mathrm{Ba}$, $\mathrm{Cu}$ and tetraphasic sol of $\mathrm{Bi}, \mathrm{Sr}, \mathrm{Ca}$ and $\mathrm{Cu}$ on $\mathrm{MgO}$ and $\mathrm{SrTiO}_{3}$ substrates. The triphasic sol coated on $\mathrm{SrTiO}_{3}$ substrates and calcined at $800^{\circ} \mathrm{C}$ for $12 \mathrm{~h}$ showed the formation of superconducting phase, $\mathrm{YBa}_{2} \mathrm{Cu}_{3} \mathrm{O}_{7-x}$ with preferred orientation along the $\mathrm{C}$-axis. X-ray diffraction patterns of the $\mathrm{Bi}_{2} \mathrm{Sr}_{2} \mathrm{CaCu}_{2} \mathrm{O}_{8+x}$ films on $\mathrm{MgO}$ substrate showed the formation of the superconducting phase with preferential orientation along the $\mathrm{C}$-axis and the microwave absorption data as a function of temperature of this film revealed the onset temperature to be $90^{\circ} \mathrm{K}$.
\end{abstract}

Keywords. High temperature superconductors; sol-gel; thin film; $\mathrm{YBa}_{2} \mathrm{Cu}_{3} \mathrm{O}_{7-x}$; $\mathrm{Bi}_{2} \mathrm{Sr}_{2} \mathrm{CaCu}_{2} \mathrm{O}_{8+x}$.

\section{Introduction}

Innovative materials processing is the key to technological utilization of the new high temperature superconductors such as $\mathrm{YBa}_{2} \mathrm{Cu}_{3} \mathrm{O}_{7-x}$ and $\mathrm{Bi}_{2} \mathrm{Sr}_{2} \mathrm{CaCu}_{2} \mathrm{O}_{8+x}$. The vast majority of syntheses of these superconductors to date involved conventional solidstate reactions of the starting materials, $\mathrm{Y}_{2} \mathrm{O}_{3}, \mathrm{CuO}, \mathrm{Bi}_{2} \mathrm{O}_{3}, \mathrm{BaCO}_{3}, \mathrm{CaCO}_{3}$ and $\mathrm{SrCO}_{3}$ which need high temperatures and long reaction times. The key factor for the preparation of these materials at low temperatures is the synthesis of precursors through simple solution chemistry. Generating new precursors of these high $T_{c}$ oxide materials through low temperature molecular chemistry is particularly important from the standpoints of powder homogeneity, purity and reproducibility. Solution routes, especially the SSG route is also ideal for low temperature processing of bulk materials, fibres, composites and coatings or thin films (Yoldas and O'keefe 1979; Dislich and Hussmann 1981; Hoffman et al 1984). A recent innovation of the SSG method is the utilization of heterogeneity on a nanometer scale and has been found to have profound effects on lowering the processing temperatures (Roy 1987). We have reported earlier the preparation of $\mathrm{YBa}_{2} \mathrm{Cu}_{3} \mathrm{O}_{7-x}$ through this process at a very low temperature (Ravindranathan et al 1988). This paper reviews the SSG process developed in our laboratory for the preparation of both $\mathrm{YBa}_{2} \mathrm{Cu}_{3} \mathrm{O}_{7-x}$ and $\mathrm{Bi}_{2} \mathrm{Sr}_{2} \mathrm{CaCu}_{2} \mathrm{O}_{8+x}$ in bulk as well as in thin film forms. 


\section{Experimental}

\subsection{Synthesis of bulk materials of $\mathrm{YBa}_{2} \mathrm{Cu}_{3} \mathrm{O}_{7-x}$}

A non-aqueous sol of copper oxide was prepared by dissolving anhydrous copper acetate, $\mathrm{Cu}\left(\mathrm{CH}_{3} \mathrm{COO}\right)_{2}$ in methoxyethanol at $70^{\circ} \mathrm{C}$, and refluxing the solution at $135^{\circ} \mathrm{C}$ for $15-20 \mathrm{~h}$. A brown solid separated out from the solution that was found to be fine-particle $\mathrm{CuO}$, as confirmed by powder X-ray diffraction (XRD). Yttrium acetate was dissolved by heating in methoxyethanol at $70^{\circ} \mathrm{C}$, and refluxing at $135^{\circ} \mathrm{C}$ for $12 \mathrm{~h}$, which resulted in a brown coloured solution, probably the ethoxide derivative of yttrium. To this solution, stoichiometric amount of barium isopropoxide was added and the mixture heated at $70^{\circ} \mathrm{C}$ for a few hours. The copper sol was then added to this mixture at room temperature and stirred well. All these reactions were carried out in argon atmosphere. A slight excess of deionized water mixed with methoxyethanol in $1: 4$ ratio was added for hydrolysis and the mixture was refluxed for $6-10 \mathrm{~h}$. The metal oxides were precipitated quantitatively from the reaction mixture by simultaneous hydrolytic decomposition of the alkoxides. The intimately mixed triphasic sol was dried at $175^{\circ} \mathrm{C}$ for a few hours. The resulting gel was finely ground and calcined at various temperatures.

\subsection{Preparation of thin films of $\mathrm{YBa}_{2} \mathrm{Cu}_{3} \mathrm{O}_{7-x}$}

Thin films of $\mathrm{YBa}_{2} \mathrm{Cu}_{3} \mathrm{O}_{7-x}$ were made by dropping the above triphasic sol on the cleaned $\mathrm{SrTiO}_{3}$ (hot pressed) substrate and spin casting with a speed of $2000 \mathrm{rpm}$ for 30 seconds. After coating the first layer of the sol, the film was dried at $175^{\circ} \mathrm{C}$ using an infrared lamp for one minute. The drying process was repeated after each coating of the sol and substrates with 10 layers were prepared to achieve sufficient film thickness. The films on the substrates were then calcined at $800^{\circ} \mathrm{C}$ for $12 \mathrm{~h}$ and annealed in $\mathrm{O}_{2}$ atmosphere at $500^{\circ} \mathrm{C}$ for $5 \mathrm{~h}$.

\subsection{Synthesis of bulk materials of $\mathrm{Bi}_{2} \mathrm{Sr}_{2} \mathrm{CaCu}_{2} \mathrm{O}_{8+x}$}

A tetraphasic sol containing $\mathrm{Bi}, \mathrm{Sr}, \mathrm{Ca}$ and $\mathrm{Cu}$ was prepared using bismuth nitrate, $\mathrm{Bi}\left(\mathrm{NO}_{3}\right)_{3} .5 \mathrm{H}_{2} \mathrm{O}(0.03 \mathrm{~mol})$, strontium metal $(0.03 \mathrm{~mol})$, calcium metal $(0.015 \mathrm{~mol})$ and copper acetate $(0.03 \mathrm{~mol})$ and the detailed procedure is outlined in figure 1 . The resulting homogeneous mixed sol can be gelled and processed into bulk materials or thin films (figure 1) of $\mathrm{Bi}_{2} \mathrm{Sr}_{2} \mathrm{CaCu}_{2} \mathrm{O}_{8+x}$. The gel powders calcined at $800^{\circ} \mathrm{C}$ for $12 \mathrm{~h}$ were made into pellets and sintered at $870^{\circ} \mathrm{C}$ for $12 \mathrm{~h}$.

\subsection{Preparation of thin films of $\mathrm{Bi}_{2} \mathrm{Sr}_{2} \mathrm{CaCu}_{2} \mathrm{O}_{8+x}$}

The intimately mixed sols (tetraphasic) were used to make films both on $\mathrm{SrTiO}_{3}$ (hotpressed) and single crystal $\mathrm{MgO}$ substrates. A small amount of cladan binder was added to adjust the viscosity of these sols and the films were coated using a spin coater. The sol was spin casted on the substrate at a speed of $2000 \mathrm{rpm}$ for 45 seconds. After each coating, the film was dried at $100^{\circ} \mathrm{C}$. About ten layers were coated to achieve sufficient thickness and calcined at $800^{\circ} \mathrm{C}$ for $6 \mathrm{~h}$ followed by another calcination at $870^{\circ} \mathrm{C}$ for 10 minutes in air. 


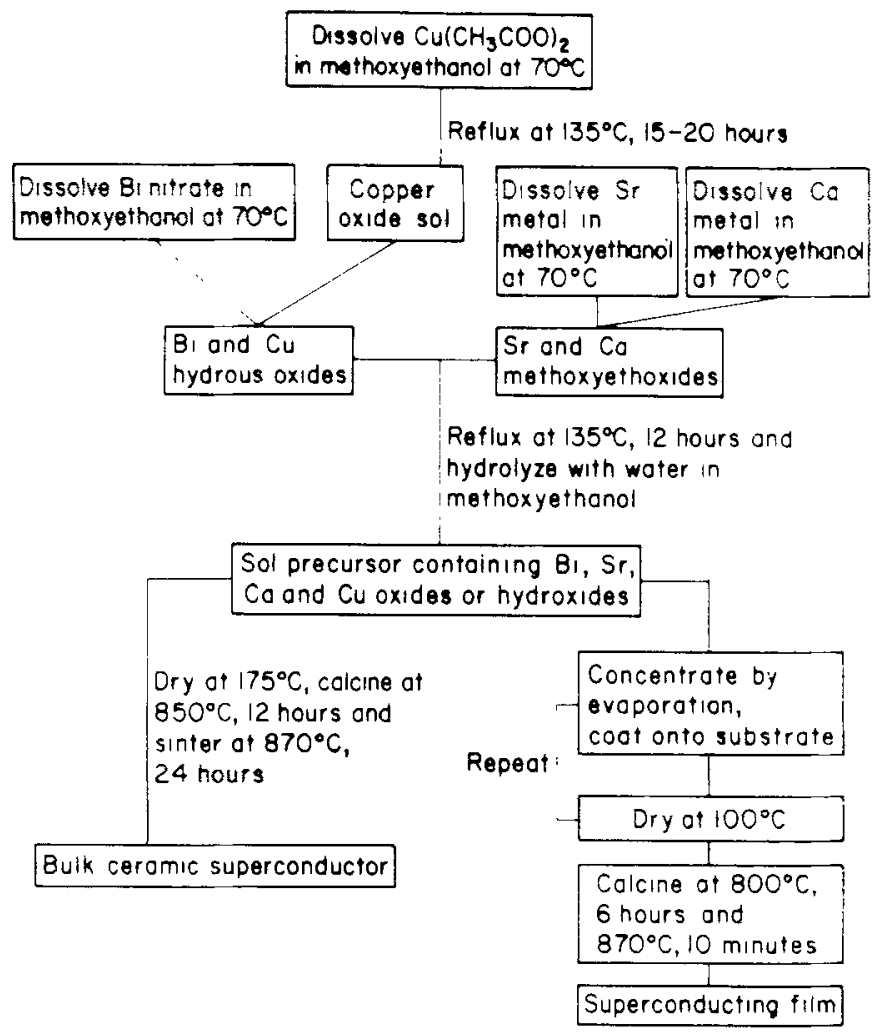

Figure 1. Flow chart for the preparation of bulk materials and thin films of $\mathrm{Bi}_{2} \mathrm{Sr}_{2} \mathrm{CaCu}_{2} \mathrm{O}_{8+x}$.

\section{Characterization}

Formation of the superconducting oxide phases was confirmed by XRD. The superconducting nature of the bulk materials was confirmed by measuring the resistance of the samples as a function of temperature by the standard four-probe technique. Inductance was also measured on bulk samples to verify the superconducting behaviour. The surface morphology of the films was characterized by scanning electron microscopy (SEM). The superconducting nature of $\mathrm{Bi}_{2} \mathrm{Sr}_{2} \mathrm{CaCu}_{2} \mathrm{O}_{8+x}$ film on $\mathrm{MgO}$ substrate was confirmed by measuring the microwave absorption as a function of temperature (Jackson et al 1988).

\section{Results and Discussion}

The as-prepared triphasic gel containing yttrium, barium and copper was amorphous and the gel calcined at $800^{\circ} \mathrm{C}$ showed the formation of single phase $\mathrm{YBa}_{2} \mathrm{Cu}_{3} \mathrm{O}_{7-x}$. When the calcination temperature was raised to $900 \mathrm{C}$ for $12 \mathrm{~h}$, the phase could be indexed on an orthorhombic unit cell as reported by Wong- $\mathrm{Ng}$ et al (1987). The 
advantages of this method are (a) it does not require repeated calcination and (b) a single phase can be obtained within $12 \mathrm{~h}$. Others, however, reported a much longer time for calcination to achieve a single phase. The powders calcined at $800^{\circ} \mathrm{C}$ were made into pellets and sintered in air at $930^{\circ} \mathrm{C}$ for $12 \mathrm{~h}$. Then the pellets were annealed at $450^{\circ} \mathrm{C}$ for $5 \mathrm{~h}$ in $\mathrm{O}_{2}$ atmosphere. XRD of the above annealed pellet showed the formation of orthorhombic $\mathrm{YBa}_{2} \mathrm{Cu}_{3} \mathrm{O}_{7-x}$ phase. The resistance curve (figure 2) showed sharp superconducting transitions $\left(\sim 90^{\circ} \mathrm{K}\right)$ with widths less than $3^{\circ} \mathrm{K}$ from the onset to zero

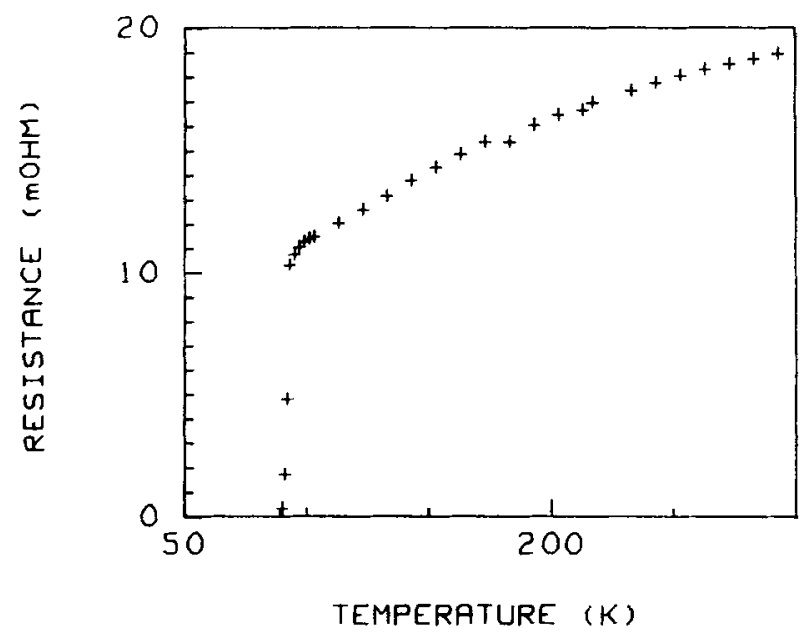

Figure 2. Temperature dependence of electrical resistance for the sol-gel derived bulk $\mathrm{YBa}_{2} \mathrm{Cu}_{3} \mathrm{O}_{7-x}$.

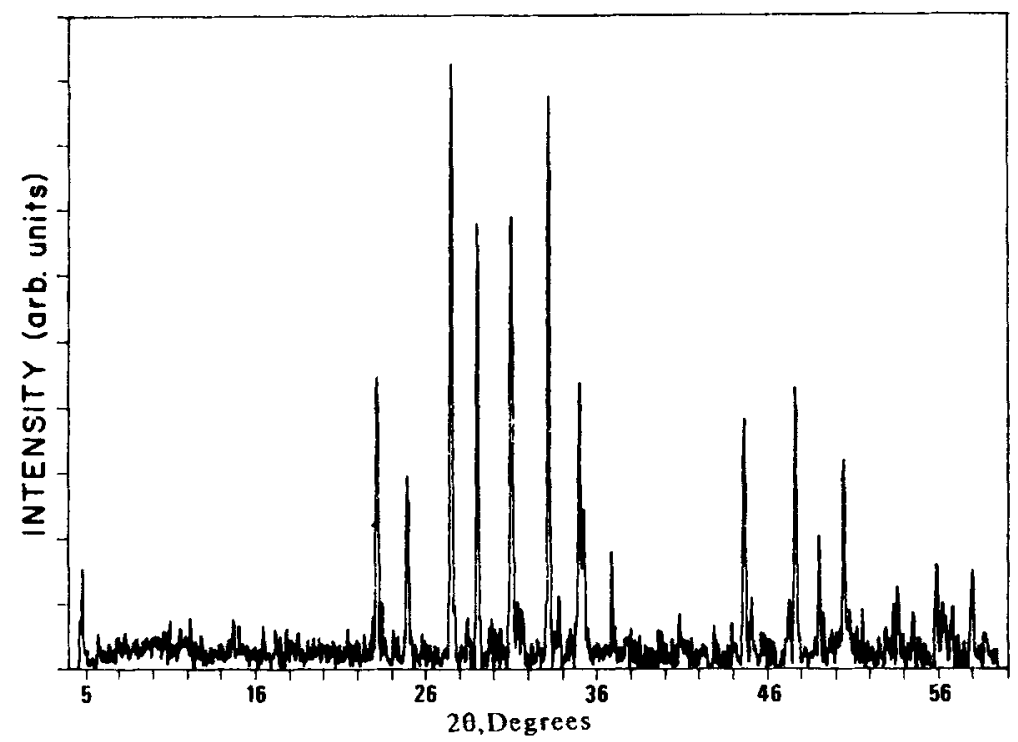

Figure 3. X-ray powder diffraction pattern of $\mathrm{Bi}_{2} \mathrm{Sr}_{2} \mathrm{CaCu}_{2} \mathrm{O}_{8+x}$ pellet (made from powders calcined at $800^{\circ} \mathrm{C}$ for $12 \mathrm{~h}$ ) sintered at $870^{\circ} \mathrm{C}$ for $12 \mathrm{~h}$. 
resistance. The inductance measurement also showed a sharp fall at the same temperature.

The $\mathrm{YBa}_{2} \mathrm{Cu}_{3} \mathrm{O}_{7-x}$ film coated on $\mathrm{SrTiO}_{3}$ substrate was calcined at $800^{\circ} \mathrm{C}$ for $12 \mathrm{~h}$ and annealed at $500^{\circ} \mathrm{C}$ for $5 \mathrm{~h}$ in $\mathrm{O}_{2}$ atmosphere. XRD of this thin film showed the formation of the superconducting phase. The sample surface was smooth and black in colour. The thickness of the film was about $2 \mu \mathrm{m}$. The XRD also showed that the film was preferentially oriented along the $C$-axis.

The tetraphasic gel powder containing $\mathrm{Bi}, \mathrm{Sr}, \mathrm{Ca}, \mathrm{Cu}$ showed the formation of $\mathrm{Bi}_{2} \mathrm{Sr}_{2} \mathrm{CaCu}_{2} \mathrm{O}_{8+x}$ upon calcination at $850^{\circ} \mathrm{C}$ for $12 \mathrm{~h}$. The XRD pattern of a pellet that was sintered at $870^{\circ} \mathrm{C}$ for $12 \mathrm{~h}$ is shown in figure 3 where it can be seen that the diffraction pattern is characteristic of the $\mathrm{Bi}_{2} \mathrm{Sr}_{2} \mathrm{CaCu}_{2} \mathrm{O}_{8+x}$ phase. The electrical resistance measured as a function of temperature showed that the onset of $T_{c}$ occurred at $\sim 85^{\circ} \mathrm{C}$ but zero resistance was achieved at $\sim 67^{\circ} \mathrm{K}$. Scanning electron micrograph of the fracture surface of the pellet showed plate-like morphology which is typical of this superconducting phase.

The films coated on $\mathrm{MgO}$ and $\mathrm{SrTiO}_{3}$ substrates using the tetraphasic sol were calcined at $800^{\circ} \mathrm{C}$ for $6 \mathrm{~h}$ and then annealed at $850^{\circ} \mathrm{C}$ and $870^{\circ} \mathrm{C}$ for 10 minutes. XRD analysis of the film annealed at $850^{\circ} \mathrm{C}$ indicated the presence of superconducting phase, $\mathrm{Ei}_{2} \mathrm{Sr}_{2} \mathrm{CaCu}_{2} \mathrm{O}_{8+x}$, semiconducting phase and some other unidentified phase whereas the film calcined at $870 \mathrm{C}$ showed only the formation of superconducting and semiconducting phases. XRD pattern of the film annealed at $870^{\circ} \mathrm{C}$ for 10 minutes on $\mathrm{MgO}$ substrate is shown in figure 4. A strong preferred orientation along the $C$-axis of the superconducting phase was observed in the XRD pattern with the $C$-axis oriented normal to the plane of the film. All the (001) reflections of the film showed high intensity (figure 4). It appears that the films prepared by this method are similar to those

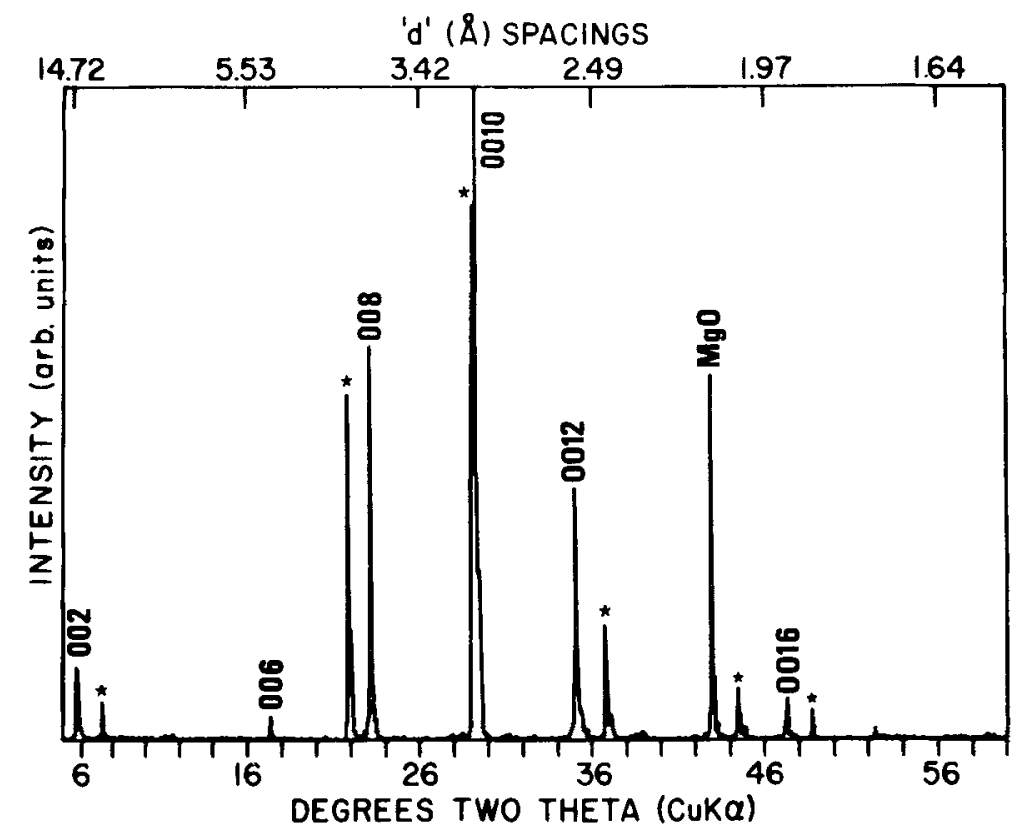

Figure 4. X-ray powder diffraction pattern of highly oriented thin film of $\mathrm{Bi}_{2} \mathrm{Sr}_{2} \mathrm{CaCu}_{2} \mathrm{O}_{8+x}$ on $\mathrm{MgO}$ substrate. 


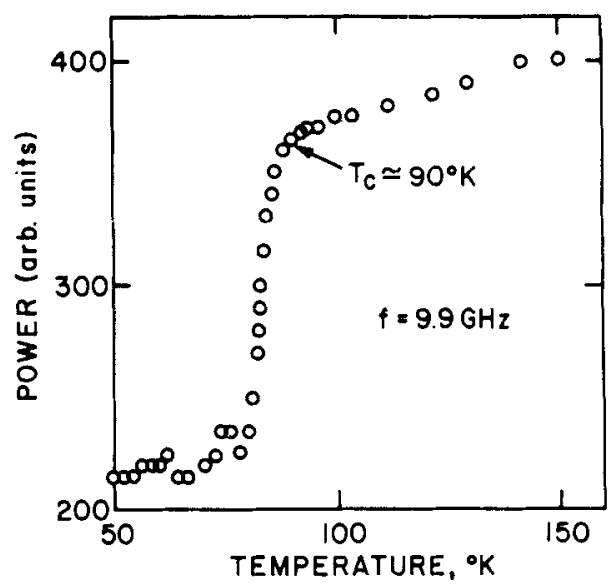

Figure 5. Temperature dependence of the power $P$ reflected by $\mathrm{Bi}_{2} \mathrm{Sr}_{2} \mathrm{CaCu}_{2} \mathrm{O}_{8+x}$ film on $\mathrm{MgO}$ substrate.

prepared by coevaporation or sputtering. The $C$-axis spacing observed in this film was $3.04 \mathrm{~nm}$, which is slightly smaller than the $3.078 \mathrm{~nm}$ spacing that was determined for bulk materials (Hazen et al 1988). The small peaks marked with an asterisk (figure 4) may be assigned to the semiconducting phase with $C=2.44 \mathrm{~nm}$ as reported by Sunshine et al (1988). The microstructure of the film showed plate-like grains which was also observed by Shah et al (1988). It also revealed a rough surface with a grain size in the 5-8 $\mu \mathrm{m}$ range. The microwave absorption of the film was measured as a function of temperature and the plot of the power $P$, reflected by the sample vs temperature is shown in figure 5 . It is clearly seen that the onset of superconductivity occurred at $90^{\circ} \mathrm{K}$ and the corresponding sharp change in the reflected power. The film coated on $\mathrm{SrTiO}_{3}$ substrate also showed clear evidence for $C$-axis orientation normal to the plane of the film (figure not shown). The resistivity versus temperature measurement revealed that the $T_{c}$ onset occurred at $80^{\circ} \mathrm{K}$ for this sample. The microstructure of this film also showed plate-like grains, as expected.

\section{Summary}

A nanocomposite sol-gel method has been developed for making both bulk and thin film materials of the high temperature superconductors, $\mathrm{YBa}_{2} \mathrm{Cu}_{3} \mathrm{O}_{7-x}$ and $\mathrm{Bi}_{2} \mathrm{Sr}_{2} \mathrm{CaCu}_{2} \mathrm{O}_{8+x}$. Superconducting oxides were prepared at temperatures as low as $750^{\circ} \mathrm{C}$ and $850^{\circ} \mathrm{C}$ for $\mathrm{YBa}_{2} \mathrm{Cu}_{3} \mathrm{O}_{7-x}$ and $\mathrm{Bi}_{2} \mathrm{Sr}_{2} \mathrm{CaCu}_{2} \mathrm{O}_{8+x}$, respectively. The superconducting transition temperatures occurred at $\sim 90^{\circ} \mathrm{K}$ for $\mathrm{YBa}_{2} \mathrm{Cu}_{3} \mathrm{O}_{7-x}$ and $\sim 67^{\circ} \mathrm{K}$ for $\mathrm{Bi}_{2} \mathrm{Sr}_{2} \mathrm{CaCu}_{2} \mathrm{O}_{8+x}$. Highly oriented films of $\mathrm{YBa}_{2} \mathrm{Cu}_{3} \mathrm{O}_{7-x}$ and $\mathrm{Bi}_{2} \mathrm{Sr}_{2} \mathrm{CaCu}_{2} \mathrm{O}_{8+x}$ were prepared on $\mathrm{MgO}$ and $\mathrm{SrTiO}_{3}$ substrates by using this $\mathrm{SSG}$ route. The microwave absorption of the $\mathrm{Bi}_{2} \mathrm{Sr}_{2} \mathrm{CaCu}_{2} \mathrm{O}_{8+x}$ film on $\mathrm{MgO}$ substrate showed the onset of $T_{c}$ to be $90^{\circ} \mathrm{K}$. 


\section{Acknowledgements}

This work was supported by the ONR-DARPA Grant under Contract No. N0001486-K-0767 and Army.

\section{References}

Dislich H and Hussmann E 1981 Thin Solid Films 77129

Hazen R M. Prewitt C T and Angel R J 1988 Phys. Ret. Lett. 601174

Hoffman D, Roy R and Komarneni S 1984 Mater. Lett. 2245

Jackson E M, Liao S B, Silvis J, Swihart A H, Bhagat S M, Crittenden R, Glover III R E and Manheimer M A 1988 Phrsica C152 125

Ravindranathan P, Komarneni S, Bhalla A S, Roy R and Cross L E 1988 J. Mater. Res. 3810

Roy R 1987 Science 2381664

Shah S I, Jones G A and Subramaniam M A 1988 Appl. Phys. Lett. 53429

Sunshine S A. Siegrist T. Schneemeyer L F, Murphy D W, Cava R J, Batlogg B, van Dover R B, Fleming R M, Glarum S H, Nakahara S, Farrow R. Krajewski J J, Zahurak S M, Waszczak S M, Marshall J H, Marsh P. Rupp Jr L W and Peck W F 1988 Phys. Rev. B38 893

Wong-Ng W, Roth R S, Swartzendruber L J, Bennett L. H. Chiang C K. Beech F and Hubbard C R 1987 Adl. Ceram. Mater. 2365

Yoldas B E and O'keefe T W 1979 Appl. Opt. 183133 